\title{
Prenatal Programming of Hypertension in the Rat: Effect of Postnatal Rearing
}

\author{
Sabeen Habib ${ }^{a}$ Qiuyu Zhang ${ }^{a}$ Michel Baum ${ }^{a, b}$ \\ Departments of a Pediatrics and ${ }^{\mathrm{b}}$ Internal Medicine, University of Texas Southwestern \\ Medical Center at Dallas, Dallas, Tex., USA
}

\section{Key Words}

Barker hypothesis $\cdot$ Blood pressure $\cdot$ Dietary protein deprivation $\cdot$ Glomerular number

\begin{abstract}
Background/Aims: Dietary protein deprivation during pregnancy causes hypertension in offspring when they become adults. This study examined if postnatal rearing had an effect on blood pressure and glomerular number in male rats whose mothers were fed either a control diet or a low protein diet. Methods: Neonates were cross fostered at 1 day of age to a different mother. After birth, all nursing and weaned rats were fed a control diet. Blood pressure and glomerular number were measured in adult offspring. Results: Control rats cross fostered to another control mother had a lower blood pressure than low protein rats cross fostered to another low protein mother (133 \pm 4 vs. $151 \pm 4 \mathrm{~mm} \mathrm{Hg}, \mathrm{p}<0.05)$ and a greater number of glomeruli $(28,388 \pm 989$ vs. $25,045 \pm 851, p<0.05)$. Fostering pups from the $20 \%$ group to mothers that were fed a $6 \%$ diet during pregnancy did not cause hypertension or a reduction in the number of glomeruli. However, fostering the $6 \%$ group on to mothers that were fed a $20 \%$ protein diet during pregnancy resulted in normalization of the blood pressure and number of glomeruli. Conclusion: The hypertension and reduced glomerular number resulting from prenatal dietary protein deprivation can be normalized by improving the postnatal environment.
\end{abstract}

Copyright ๑ 2011 S. Karger AG, Basel 


\section{Introduction}

Barker and coworkers were the first to recognize that prenatal insults are a risk factor for hypertension and cardiovascular disease [1-4]. Animal models, including dietary protein deprivation, prenatal administration of dexamethasone and uterine-placental insufficiency, have been used to study the mechanism of how prenatal insults lead to cardiovascular disease in later life. In rodents and sheep, prenatal insults result in hypertension and a reduction in the glomerular number when offspring are studied as adults [5-16]. The cause for the hypertension is likely multifactorial [16].

In addition to the importance of the prenatal environment affecting adult disease, there is evidence from epidemiological studies that postnatal growth may also be a factor affecting health in later life. Small for gestational age infants who were thin at 2 years and have accelerated growth after that time are at risk for cardiovascular disease and elevated fasting insulin levels [17]. Similarly, low birth weight infants who have rapid weight gain in childhood are at risk for the development of hypertension as adults [18-20].

Nephrogenesis continues in the rat for approximately 10 days after birth as in the human neonate born before 34-36 weeks gestation. Thus, the postnatal environment could affect renal development in premature infants born before nephrogenesis has been completed and for several days after birth in rats. Recent studies have shown that the postnatal environment can affect the endowment of nephrons in rats as well as blood pressure [21-25]. Our group and others has shown that maternal dietary protein deprivation in rats leads to hypertension in offspring when studied as adults $[13,16]$. The aim of the present study was to examine if altering postnatal rearing of neonates whose mothers were exposed to either a normal or a low protein diet would affect blood pressure and glomerular number when the neonates were studied as adults.

\section{Methods}

\section{Animals}

Pregnant rats were fed either a $6 \%$ protein diet (low protein) or an isocaloric diet containing $20 \%$ protein (control diet) from day 12 of gestation until birth, as previously described $[16,26]$. All mothers were fed a $20 \%$ protein diet after delivery. There was no difference in the number of pups in the two groups (11.4 \pm 0.6 pups in the control and $13.0 \pm 0.5$ pups in the low protein group; nonsignificant). After birth, the litters were all reduced to 8-10 rats to reduce variability. At 25 days of age, the rats were weaned from their mothers. The rats were weighed at 1,10 and 60 days of age. No pregnant mother was used more than once. Only males were studied to lessen the variability and because males are affected by prenatal programming more severely than females $[9,15,27]$. These studies were approved by the Institutional Animal Care and Use Committee of the University of Texas Southwestern Medical Center.

Four groups of animals were studied to examine the effect of postnatal rearing on prenatal programming. In one group, control dams reared another group of control pups (Control $\rightarrow$ Control). We also had low protein pups cross fostered to another low protein dam $(\mathrm{LP} \rightarrow \mathrm{LP})$. To determine if the effects of prenatal low protein diet could be ameliorated by postnatal rearing, some of the low protein pups were cross fostered to control dams $(\mathrm{LP} \rightarrow \mathrm{Control}$ ). Finally, to determine if postnatal rearing to a mother who was on a low protein diet during gestation was deleterious, some control pups were raised by mothers who were on a low protein diet during the last half of gestation (Control $\rightarrow$ LP). All pups were switched on the 1st day of life. 
We also examined two additional groups of rats whose pups were raised by their own mothers to determine if cross rearing affected blood pressure or glomerular number. We compared the control rats raised by a different group of control mothers to control rats raised by their own mother. We also compared low protein rats raised by their own mother to low protein rats raised by a different low protein mother.

\section{Measurement of Blood Pressure}

Blood pressure was measured at 10 weeks of age by tail cuff using a blood pressure analyzer (model 179; IITC, Woodland Hills, Calif., USA). Rats were trained for 4 days by placing rats in a Lucite tube and inflating the tail blood pressure cuff several times 1 day prior to the actual measurement of blood pressure on the 5th day. Blood pressure was measured at least four times in each rat, and the mean of the values was used as the blood pressure for that rat. The investigator who measured the blood pressure was blinded to the origin of the rats being studied.

\section{Glomerular Number}

The number of glomeruli was determined using the maceration technique previously utilized by our laboratory and others $[8,9,13,28,29]$. This technique results in the same number of nephrons in rats as other techniques, such as the dissector method $[25,30]$. The rats were anesthetized with Inactin (100 mg/kg body weight; Sigma, St. Louis, Mo., USA). The femoral artery was catheterized with polyethylene tubing advanced to a level above the renal artery. Five percent Alcian blue (Sigma) dissolved in isotonic saline was infused at a dose of $0.3 \mathrm{ml} / 100 \mathrm{~g}$ body weight over $30 \mathrm{~s}$ [8]. A second dose of $0.3 \mathrm{ml}$ Alcian blue $/ 100 \mathrm{~g}$ body weight was administered as a bolus a few minutes after the first infusion. Five minutes after the second bolus, the kidney was removed and the capsule was discarded. The kidney was minced using a single edged razor blade, placed in $1 \%$ ammonium chloride solution (Sigma) and incubated for $5 \mathrm{~min}$ at room temperature. The tissue was then incubated with gentle agitation in $5 \mathrm{ml}$ of $50 \% \mathrm{HCl}(6 \mathrm{~N})$ in a water bath at $37^{\circ} \mathrm{C}$ for $90 \mathrm{~min}$. The kidney tissue was then mixed vigorously until all pieces were dissolved. The sample was then centrifuged at 3,000 rpm for $10 \mathrm{~min}$. The supernatant was discarded and the pellet was dissolved in $50 \mathrm{ml}$ of distilled water. The tube containing the glomeruli was gently shaken to insure that the glomeruli were dispersed uniformly. Thirty $10-\mu l$ samples of glomeruli were counted and the total number of glomeruli in the kidney was then determined from the mean of the number of glomeruli in $10-\mu l$ samples. The investigator that counted the glomeruli was blinded regarding the origin of the samples.

\section{Statistical Analysis}

All data are expressed as means \pm SEM. When two groups were compared, Student's t test was used. Analysis of variance with post hoc Student-Newman-Keuls test was used to determine statistical significance in comparisons of more than two groups.

\section{Results}

On day 1 of life, there was a statistically significant difference between the weight of pups born to mothers that were fed a low protein diet $(4.9 \pm 0.1 \mathrm{~g}, \mathrm{n}=139)$ compared to those whose mothers were fed a control diet $(6.3 \pm 0.1 \mathrm{~g}, \mathrm{n}=111 ; \mathrm{p}<0.001)$. The rats were then all reared by different mothers. By 10 days of age, the male rats that were born to mothers that ate a $20 \%$ protein diet and were reared by a different mother that ate a $20 \%$ protein diet weighed $22.0 \pm 0.8 \mathrm{~g}$, which was still greater than the $19.5 \pm 0.3 \mathrm{~g}$ of the low protein pups 
Fig. 1. Effect of prenatal protein and postnatal rearing on blood pressure. Control and low protein (LP) rats were raised by foster dams. Blood pressures were measured at approximately 10 weeks of age in male rats. There were 13-15 measurements in each group. The blood pressure levels in the LP $\rightarrow$ LP groups were higher than in the Control $\rightarrow$ Control and the $\mathrm{LP} \rightarrow$ Control groups $(\mathrm{p}<$ $0.05)$. The improvement in blood pressure in the low protein group raised by the control group is consistent with postnatal programming by a change in maternal rearing $\left({ }^{*} \mathrm{p}<0.05\right)$.

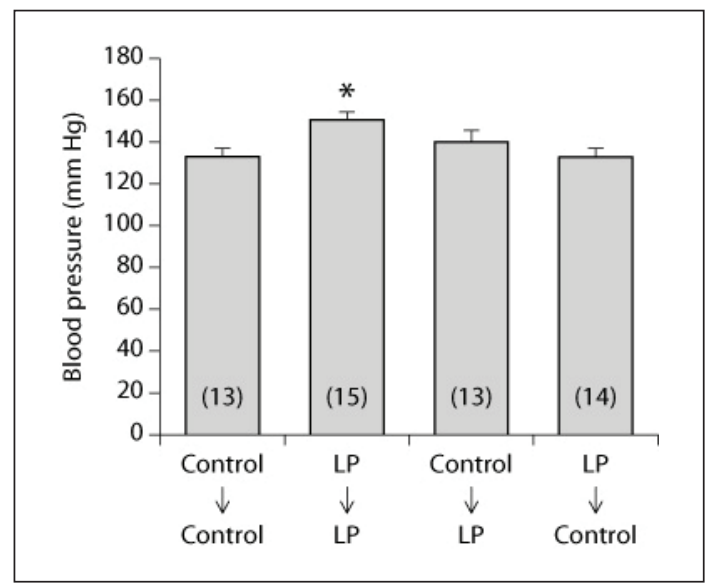

raised by a low protein mother $(\mathrm{p}<0.01)$. The control diet rats raised by a mother fed a low protein diet weighed $20.0 \pm 0.7 \mathrm{~g}$ and the low protein pups raised by mothers that ate a $20 \%$ protein diet weighed $20.6 \pm 0.6 \mathrm{~g}$, which was not different from the other groups. The low protein group raised by mothers that ate a low protein diet during pregnancy continued to weigh less than the control diet group raised by the control diet group at 60 days of age (297 \pm 3 vs. $276 \pm 3 \mathrm{~g}, \mathrm{p}<0.001$ ). However, by 60 days of age, the control group raised by the low protein mothers and the low protein offspring raised by the control group weighed $303 \pm 4$ and $295 \pm 5$ g, respectively, which was comparable to the control group raised by controls and greater than the low protein group raised by the low protein group $(\mathrm{p}<0.001)$.

At the time of sacrifice, the kidneys of the switched rats were weighed. The kidneys of the $20 \%$ group raised by a $20 \%$ foster mother weighed $1.45 \pm 0.09 \mathrm{~g}$. This kidney weight was greater than in all the other groups $(\mathrm{p}<0.05)$. The kidneys of the low protein group raised by a mother that ate a low protein diet weighed $1.21 \pm 0.05 \mathrm{~g}$, which was not different from than that of the $6 \%$ group raised by a mother who ate a $20 \%$ protein diet during pregnancy $1.27 \pm 0.03 \mathrm{~g}$, or the $20 \%$ group raised by a mother who ate a $6 \%$ diet during pregnancy $1.20 \pm 0.08 \mathrm{~g}$.

Blood pressure of control diet rats raised by their mothers was $134 \pm 5 \mathrm{~mm} \mathrm{Hg}$, which was not different from the control rats that were fostered to controls (133 $\pm 4 \mathrm{~mm} \mathrm{Hg}$ ). The blood pressure of the low protein group raised by their own mother was $150 \pm 2$ versus $151 \pm 4 \mathrm{~mm} \mathrm{Hg}$ in the $6 \%$ group raised by a low protein diet mother. Thus, switching the offspring to a comparably fed mother did not affect blood pressure.

The effect of postnatal nutrition on blood pressure is shown in figure 1. Ten-week-old low protein rat offspring that were reared by mothers fed a low protein diet had a significantly higher blood pressure than those whose mothers were fed a control diet and cross fostered to mothers that ate a control diet. The $20 \%$ group had similar blood pressure levels whether they were raised by the mothers that ate a $20 \%$ diet or a $6 \%$ protein diet. However, cross fostering the pups born to mothers who were fed a $6 \%$ protein diet to those mothers who were fed a $20 \%$ protein diet resulted in a blood pressure comparable to the $20 \%$ group raised by the $20 \%$ group and lower than the offspring of the $6 \%$ group raised by mothers who were fed a $6 \%$ protein diet. This is consistent with the postnatal environment ameliorating hypertension of rats whose mothers had dietary protein deprivation during pregnancy.

As a control, we examined if there was a difference between the numbers of glomeruli of mothers raising their own pups compared to mothers on comparable diets raising the pups. The $20 \%$ group raising their own pups had 27,805 \pm 606 glomeruli, which was no dif- 
Fig. 2. Effect of prenatal protein and postnatal rearing on glomerular number. The numbers of glomeruli were counted in rats that were approximately 60 days of age in a blinded fashion. There were 16-18 measurements in each group. The low protein group raised by the low protein dams $(\mathrm{LP} \rightarrow \mathrm{LP})$ had fewer glomeruli than the Control $\rightarrow$ Control and the LP $\rightarrow$ Control groups $\left({ }^{*} \mathrm{p}<0.05\right)$. This demonstrates that postnatal rearing can affect the number of glomeruli in rats after a prenatal insult.

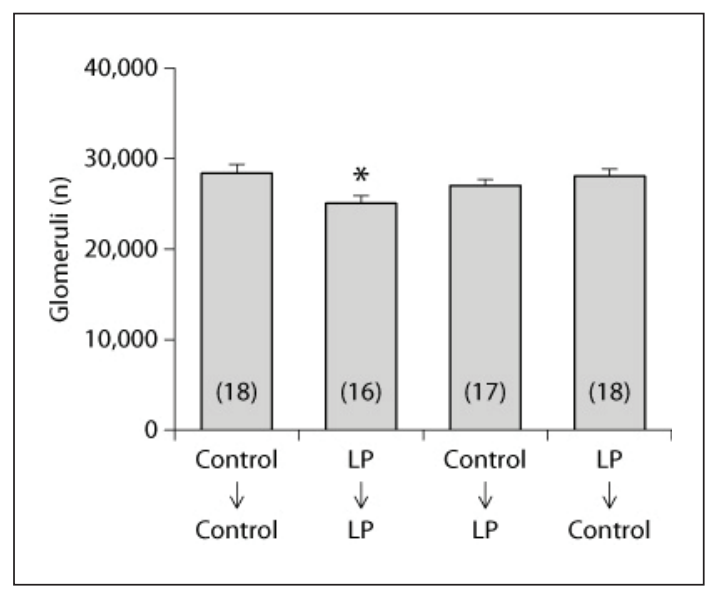

ferent from the $28,389 \pm 989$ in the $20 \%$ group that was cross fostered to the $20 \%$ group. Similarly, the low protein group raising their own pups had a similar number of glomeruli to those cross raised by another low protein mother $(25,445 \pm 685$ vs. $25,045 \pm 851$ glomeruli, respectively).

We next examined if postnatal rearing would affect the number of glomeruli to determine if postnatal rearing could affect a prenatal insult. In rats, glomeruli continue to form until $\sim 10$ days of age. Control rats that raised foster control pups had more glomeruli than the low protein group reared by a low protein foster mother (fig. 2). The number of glomeruli in the low protein group that was raised by a control diet mother also had a greater number of glomeruli than the low protein group raised by a low protein foster mother, indicating that the postnatal environment could affect the number of glomeruli.

\section{Discussion}

The present study examined if postnatal rearing could mitigate the hypertension and reduction in glomeruli seen in rats whose mothers were fed a low protein diet. We demonstrate that cross fostering prenatal low protein pups to a prenatal low protein mother resulted in an increase in blood pressure and reduction in glomerular number compared to adult offspring of a control diet mother raised by another control mother. While the control rats fostered on to the low protein diet group did not have any significant adverse effect, the rats born to mothers that ate a low protein diet but were raised by control diet rats had normalization of their blood pressure to control values and a glomerular endowment comparable to control pups raised by control mothers. Therefore, the potential of postnatal rearing may have clinical significance especially in premature infants born before 34 weeks, when nephrogenesis is still occurring.

Previous studies have examined if alteration in the postnatal caloric intake had an effect on glomerular number and blood pressure when the rats were studied as adults. Postnatal caloric deprivation induced by increasing the number of nursing rat pups to 20 compared to 10 in the control group resulted in a reduction in the number of glomeruli in the neonatally restricted rats when studied as adults [22]. The effect of a reduction in nursing rat pups on postnatal nutrition has been less clear. One group found that a reduction in the litter size from approximately 10 to 5 caused impaired postnatal weight gain, which resulted in rats that had a reduction in glomerular number and hypertension when they were studied as 
adults $[23,24]$. Interestingly, another group reduced the number of nursing pups to 3 to study the effect of overnutrition on glomerular number and blood pressure [21]. In this study, the rats weighed more until the time of weaning and had a tendency to weigh more as adults, though the latter was not statistically significant. The postnatally overfed rats had a $20 \%$ increase in glomerular number compared to controls when studied as aged adults ( 22 months), but had an increase in glomerular sclerosis and proteinuria. At 2 months of age, an age comparable to that of the present study, the postnatally overfed rats had a higher blood pressure than controls [21].

Postnatal overfeeding of rats whose mothers ate a low protein diet during gestation by reducing the number of pups to 4 and fostering the pups to a mother who ate a control diet during and after pregnancy induced significant catch-up growth [31]. However, the rats that had rapid weight gain had a reduced life span compared to control rats whose mothers ate a control diet while nursing and rats whose mothers ate a prenatal control diet but were raised by mothers that were fed low protein diet while pregnant [31]. While the above studies come to different conclusions regarding the effect of reducing litter size on postnatal growth, they show that the postnatal nutrition affects the blood pressure and glomerular number.

The cause for the elevated blood pressure due to a prenatal insult remains unclear. Dietary protein deprivation, prenatal steroids and uteroplacental insufficiency all present with a reduction in glomeruli $[8,9,13,24,25]$. Brenner and Chertow [32, 33], for example, have proposed that a reduction in nephron number is an important factor in causing an elevated blood pressure [32-35]. However, the reduction in nephrons with prenatal programming is usually approximately $20-30 \%$ and there are several studies showing a lack of correlation between the number of glomeruli and hypertension $[9,21,25,36]$. A disorder of the intrarenal renin-angiotensin system has been proposed to be involved in hypertension in prenatal programming [37-42]. Renal denervation prevents the hypertension seen in adult rats whose mothers had a prenatal insult $[11,40]$. An increase in renal transporters has been found in adult rats that sustained a prenatal insult which may cause an increase in renal sodium absorption and salt-dependent hypertension $[10,11,43,44]$. An alteration in sodium transport, the intrarenal renin-angiotensin system and renal nerves are not mutually exclusive potential causes for the hypertension by prenatal programming. Whatever the pathogenetic mechanism for the hypertension by prenatal programming, elucidation of a perinatal factor that could prevent these injuries may have significant clinical implications.

Rats with uteroplacental insufficiency give birth to neonates that are born small for gestational age have a reduced nephron number and hypertension [15, 23, 25, 45]. In a recent study, Wlodek et al. [25] firstly demonstrated that providing rats that were the product of uteroplacental insufficiency an improved lactational diet by cross fostering the rats with control mothers prevents the hypertension and reduction in nephron number. There were a number of significant differences between the current study and that by Wlodek et al. [25]. First, the means of producing the prenatal insult was substantively different in our study compared to uteroplacental insufficiency at 18 days of gestation. Prenatal programming resulting from a low protein intake results in low birth weight offspring but does not cause a reduction in the size of the litter. The average litter size with uteroplacental insufficiency is 5 pups and the control group had an average of 10 pups. As shown above, a reduction in litter size can affect postnatal growth. The previous study found that a reduced number of pups from a control mother raised by a mother that had a prenatal uterine artery ligation developed hypertension. In the current study, the control group raised by the low protein group did not have a significant increase in blood pressure. Finally, all measurements in the current study were blinded. Nonetheless, our study confirms that there is postnatal malleability of a prenatal insult that can reverse the outcome of a prenatal insult. 
There are a number of factors that may be responsible for the amelioration in blood pressure by cross fostering pups to controls. Prenatal maternal insults can affect postnatal rearing and/or lactation resulting in poor postnatal weight gain of neonates [23, 23, 46, 47]. Mothers that have uteroplacental insufficiency, created by prenatal ligation of the uterine artery on day 18 of gestation, produce less milk with altered composition, including less calcium, compared to control rats [23]. There may be other maternal behavioral factors affecting postnatal rearing as well.

In summary, the present study demonstrates that cross fostering neonates to mothers who ate the same diet does not affect blood pressure in later life. Cross fostering control rats to mothers that had dietary protein deprivation did not have a significant effect on blood pressure, while cross fostering rats from mothers that had dietary protein deprivation to controls resulted in normalization of blood pressure. These studies demonstrate the importance of postnatal rearing in hypertension due to maternal dietary protein restriction.

\section{Acknowledgments}

This work was supported by National Institutes of Health Grants DK-41612 (M.B.), DK078596-01 (M.B.) and 1P30DK079328-01 (M.B.).

\section{Disclosure Statement}

There was no conflict of interest by any of the authors.

\section{References}

1 Barker DJ: The fetal origins of adult hypertension. J Hypertens Suppl 1992;10:S39-S44.

2 Barker DJ, Godfrey KM, Osmond C, Bull A: The relation of fetal length, ponderal index and head circumference to blood pressure and the risk of hypertension in adult life. Paediatr Perinat Epidemiol 1992;6:35-44.

3 Barker DJ, Bull AR, Osmond C, Simmonds SJ: Fetal and placental size and risk of hypertension in adult life. BMJ 1990;301:259-262.

4 Barker DJ, Osmond C: Low birth weight and hypertension. BMJ 1988;297:134-135.

5 Figueroa JP, Rose JC, Massmann GA, Zhang J, Acuna G: Alterations in fetal kidney development and elevations in arterial blood pressure in young adult sheep after clinical doses of antenatal glucocorticoids. Pediatr Res 2005;58:510-515.

6 Kantorowicz L, Valego NK, Tang L, Figueroa JP, Chappell MC, Carey LC, Rose JC: Plasma and renal renin concentrations in adult sheep after prenatal betamethasone exposure. Reprod Sci 2008;15: 831-838.

7 Massmann GA, Zhang J, Rose JC, Figueroa JP: Acute and long-term effects of clinical doses of antenatal glucocorticoids in the developing fetal sheep kidney. J Soc Gynecol Investig 2006;13:174-180.

8 Ortiz LA, Quan A, Weinberg A, Baum M: Effect of prenatal dexamethasone on rat renal development. Kidney Int 2001;59:1663-1669.

9 Ortiz LA, Quan A, Zarzar F, Weinberg A, Baum M: Prenatal dexamethasone programs hypertension and renal injury in the rat. Hypertension 2003;41:328-334.

10 Dagan A, Gattineni J, Cook V, Baum M: Prenatal programming of rat proximal tubule $\mathrm{Na}^{+} / \mathrm{H}^{+}$exchanger by dexamethasone. Am J Physiol Regul Integr Comp Physiol 2007;292:R1230-R1235.

11 Dagan A, Kwon HM, Dwarakanath V, Baum M: Effect of renal denervation on prenatal programming of hypertension and renal tubular transporter abundance. Am J Physiol Renal Physiol 2008; 295:F29-F34. 


\begin{tabular}{l|l}
\hline Nephron Extra 2011;1:157-165 \\
\hline DOI: 10.1159/000333477 & $\begin{array}{l}\text { @ 2011 S. Karger AG, Basel } \\
\text { www.karger.com/nne }\end{array}$ \\
Published online: October 25, 2011 &
\end{tabular}

12 Vehaskari VM, Woods LL: Prenatal programming of hypertension: lessons from experimental models. J Am Soc Nephrol 2005;16:2545-2556.

13 Vehaskari VM, Aviles DH, Manning J: Prenatal programming of adult hypertension in the rat. Kidney Int 2001;59:238-245.

14 Alexander BT: Fetal programming of hypertension. Am J Physiol Regul Integr Comp Physiol 2006; 290:R1-R10.

15 Alexander BT: Placental insufficiency leads to development of hypertension in growth-restricted offspring. Hypertension 2003;41:457-462.

16 Dagan A, Habbib S, Gattineni J, Dwarakanath V, Baum M: Prenatal programming of rat thick ascending limb chloride transport by low protein diet and dexamethasone. Am J Physiol Regul Integr Comp Physiol 2009;297:R93-R99.

17 Barker DJP, Osmond C, Forsen TJ, Kajantie E, Eriksson JG: Trajectories of growth among children who have coronary events as adults. N Engl J Med 2005;353:1802-1809.

18 Eriksson JG, Forsen TJ, Kajantie E, Osmond C, Barker DJ: Childhood growth and hypertension in later life. Hypertension 2007;49:1415-1421.

19 Eriksson J, Forsen T, Tuomilehto J, Osmond C, Barker D: Fetal and childhood growth and hypertension in adult life. Hypertension 2000;36:790-794.

20 Law CM, Shiell AW, Newsome CA, Syddall HE, Shinebourne EA, Fayers PM, Martyn CN, de Swiet M: Fetal, infant, and childhood growth and adult blood pressure: a longitudinal study from birth to 22 years of age. Circulation 2002;105:1088-1092.

21 Boubred F, Buffat C, Feuerstein JM, Daniel L, Tsimaratos M, Oliver C, Lelievre-Pegorier M, Simeoni $\mathrm{U}$ : Effects of early postnatal hypernutrition on nephron number and long-term renal function and structure in rats. Am J Physiol Renal Physiol 2007;293:F1944-F1949.

22 Schreuder MF, Nyengaard JR, Remmers F, van Wijk JAE, Delemarre-van de Waal HA: Postnatal food restriction in the rat as a model for a low nephron endowment. Am J Physiol Renal Physiol 2006; 291:F1104-F1107.

23 O’Dowd R, Kent JC, Moseley JM, Wlodek ME: Effects of uteroplacental insufficiency and reducing litter size on maternal mammary function and postnatal offspring growth. Am J Physiol Regul Integr Comp Physiol 2008;294:R539-R548.

24 Wlodek ME, Westcott K, Siebel AL, Owens JA, Moritz KM: Growth restriction before or after birth reduces nephron number and increases blood pressure in male rats. Kidney Int 2008;74:187-195.

25 Wlodek ME, Mibus A, Tan A, Siebel AL, Owens JA, Moritz KM: Normal lactational environment restores nephron endowment and prevents hypertension after placental restriction in the rat. J Am Soc Nephrol 2007;18:1688-1696.

26 Manning J, Vehaskari VM: Low birth weight-associated adult hypertension in the rat. Pediatr Nephrol 2001;16:417-422.

27 Woods LL, Ingelfinger JR, Rasch R: Modest maternal protein restriction fails to program adult hypertension in female rats. Am J Physiol Regul Integr Comp Physiol 2005;289:R1131-R1136.

28 Bankir L, Hollenberg NK: In vivo staining of the kidney with Alcian blue: an adjunct to morphological and physiological studies. Ren Physiol 1983;6:151-155.

29 Fassi A, Sangalli F, Maffi R, Colombi F, Mohamed EI, Brenner BM, Remuzzi G, Remuzzi A: Progressive glomerular injury in the MWF rat is predicted by inborn nephron deficit. J Am Soc Nephrol 1998;9:1399-1406.

30 Woods LL, Ingelfinger JR, Nyengaard JR, Rasch R: Maternal protein restriction suppresses the newborn renin-angiotensin system and programs adult hypertension in rats. Pediatr Res 2001;49:460467.

31 Jennings BJ, Ozanne SE, Dorling MW, Hales CN: Early growth determines longevity in male rats and may be related to telomere shortening in the kidney. FEBS Lett 1999;448:4-8.

32 Brenner BM, Chertow GM: Congenital oligonephropathy and the etiology of adult hypertension and progressive renal injury. Am J Kidney Dis 1994;23:171-175.

33 Brenner BM, Chertow GM: Congenital oligonephropathy: an inborn cause of adult hypertension and progressive renal injury? Curr Opin Nephrol Hypertens 1993;2:691-695.

34 Brenner BM, Garcia DL, Anderson S: Glomeruli and blood pressure. Less of one, more the other? Am J Hypertens 1988;1:335-347.

35 Mackenzie HS, Lawler EV, Brenner BM: Congenital oligonephropathy: the fetal flaw in essential hypertension? Kidney Int Suppl 1996;55:S30-S34. 
36 Black MJ, Briscoe TA, Constantinou M, Kett MM, Bertram JF: Is there an association between level of adult blood pressure and nephron number or renal filtration surface area? Kidney Int 2004;65: $582-588$.

37 Langley-Evans SC, Jackson AA: Captopril normalizes systolic blood pressure in rats with hypertension induced by fetal exposure to maternal low protein diets. Comp Biochem Physiol A Physiol 1995; 110:223-228.

38 Manning J, Vehaskari VM: Postnatal modulation of prenatally programmed hypertension by dietary $\mathrm{Na}$ and ACE inhibition. Am J Physiol Regul Integr Comp Physiol 2005;288:R80-R84.

39 Grigore D, Ojeda NB, Robertson EB, Dawson AS, Huffman CA, Bourassa EA, Speth RC, Brosnihan $\mathrm{KB}$, Alexander BT: Placental insufficiency results in temporal alterations in the renin angiotensin system in male hypertensive growth restricted offspring. Am J Physiol Regul Integr Comp Physiol 2007;293:R804-R811.

40 Alexander BT, Hendon AE, Ferril G, Dwyer TM: Renal denervation abolishes hypertension in lowbirth-weight offspring from pregnant rats with reduced uterine perfusion. Hypertension 2005;45: 754-758.

41 Ojeda NB, Johnson WR, Dwyer TM, Alexander BT: Early renal denervation prevents development of hypertension in growth-restricted offspring. Clin Exp Pharmacol Physiol 2007;34:1212-1216.

42 Dagan A, Gattineni J, Habib S, Baum M: Effect of prenatal dexamethasone on postnatal serum and urinary angiotensin II levels. Am J Hypertens 2010;23:420-424.

43 Bertram C, Trowern AR, Copin N, Jackson AA, Whorwood CB: The maternal diet during pregnancy programs altered expression of the glucocorticoid receptor and type $211 \beta$-hydroxysteroid dehydrogenase: potential molecular mechanisms underlying the programming of hypertension in utero. Endocrinology 2001;142:2841-2853.

44 Manning J, Beutler K, Knepper MA, Vehaskari VM: Upregulation of renal BSC1 and TSC in prenatally programmed hypertension. Am J Physiol Renal Physiol 2002;283:F202-F206.

45 Moritz KM, Mazzuca MQ, Siebel AL, Mibus A, Arena D, Tare M, Owens JA, Wlodek ME: Uteroplacental insufficiency causes a nephron deficit, modest renal insufficiency but no hypertension with ageing in female rats. J Physiol 2009;587:2635-2646.

46 Siebel AL, Mibus A, De Blasio MJ, Westcott KT, Morris MJ, Prior L, Owens JA, Wlodek ME: Improved lactational nutrition and postnatal growth ameliorates impairment of glucose tolerance by uteroplacental insufficiency in male rat offspring. Endocrinology 2008;149:3067-3076.

47 Wlodek ME, Ceranic V, O'Dowd R, Westcott KT, Siebel AL: Maternal progesterone treatment rescues the mammary impairment following uteroplacental insufficiency and improves postnatal pup growth in the rat. Reprod Sci 2009;16:380-390. 